УДК 347.45/47:347.119.11](477)

DOI https://doi.org/10.32849/2663-5313/2020.4.01

ЕӘуард Бондарєв,

здобувач Харківського начіонального університету внутрішніх справ

\title{
ВІДПОВІДАЛЬНІСТЬ СТОРІН АКЦІОНЕРНОГО ДОГОВОРУ ЗА ЙОГО ПОРУШЕННЯ
}

У статті досліджується проблематика цивільно-правової відповідальності сторін акиіонерного договору. На основі поділу ивого поняття на його матеріальне та проиесуальне значення автор вважає, що в матеріальному значенні иивільно-правова відповідальність сторін такого договору - ие покарання порушника у вигляді покладення на нього додаткового обов'язку чи позбавлення того, що він уже має або міг би мати. Обгрунтовується, що порушення умов договору є підставою виникнення відповідальності для правопорушника. При цьому зазначається, що відповідальність сторін акціонерного договору може встановлюватися не лише за порушення тих прав (обов'язків), які закріплені у договорі, а й передбачених чинним законодавством, статутом та іншими внутрішніми документами товариства.

Одне з ключових питань, розглянутих у статті, - можливість застосувати такий вид відповідальності, як втрата стороною акиіонерного договору права голосу з усіх питань, що можуть розглядатися загальними зборами. Стверджується, що такий підхід повністю узгоджується з розумінням иивільно-правової відповідальності як покарання у вигляді позбавлення порушника того, шо він має або міг би мати. У цьому випадку особа позбавляється (обмежується) права голосу. Більше того, якщо акиіонерним договором встановлені певні зобов'язання щодо голосування в тій чи іншій ситуації, то у разі порушення таких зобов'язань найбільш ефективним способом попередження подальшого ix порушення в майбутньому є саме позбавлення голосу акиіонера-правопорушника. Автор статті вважає, що позбавлення права голосу може попередити і майбутні порушення виконання зобов'язань щодо голосування, хоча й без відикодування збитків, заподіяних порушенням, завданих у минулому. Відикодувати иі збитки було б можливо за допомогою того, що частина або весь прибуток товариства, який відповідно до наявних акиій у особи, яка порушила зобов'язання, могла би бути перерозподілена на покриття збитків.

Наведене свідчить про потребу проведення більш глибоких наукових досліджень иивільно-правової відповідальності учасників акціонерного договору, підстав та умов ї виникнення, підстави звільнення тощо.

Ключові слова: договір, цивільно-правова відповідальність, акціонер, акціонерний договір, заходи відповідальності, відшкодування.

Постановка проблеми. Обравши курс на євроінтеграцію, наша країна зобов'язалась адаптувати своє внутрішнє законодавство, і перш за все тих галузей права, які спрямовані на врегулювання ринкових відносин. Однією з таких галузей, безумовно, є корпоративне законодавство [1, с. 15]. Разом із тим така адаптація можлива лише за умови пізнання стану дослідження наявних проблем у вітчизняному праві. Й однією з таких проблем є відповідальність учасників акціонерного договору.

Невирішеним залишається питання не лише використання зобов'язально-правових, але й можливості застосування корпоративних способів захисту корпоративних прав акціонерів-сторін акціонерного договору. Фактично йдеться про можливість застосування саме корпоративних способів захисту прав сторін акціонерного договору у разі їх порушення, оскільки і правова доктрина, і законодавець, і судова практика виходять із того, що акціонерним договором опосередковуються виключно зобов'язальні відносини між його сторонами, що жодним чином не має впливати на корпоративні відносини в рамках акціонерного товариства.

Метою статті є встановлення відповідальності сторін акціонерного договору.

Аналіз останніх досліджень. Питанням відповідальності учасників корпоративних правовідносин тією чи іншою мірою приділяли увагу такі вчені, як: М. Варюшин, Ю. Жорнокуй, М. Іноземцев, Х. Ода, М. Сигидин, I. Спасибо-Фатеєва, М. Трубіна, Х.-Й. Шрамм та ін. Але в умовах постійних соціально-економічних змін, що відбуваються в суспільстві, та доопрацювання законодавчого масиву, що нормативно забезпечує 
сферу здійснення корпоративних прав акціонерами, вибрана тематика потребує детального аналізу як правотворчої, так і правозастосовної діяльності з метою проведення подальших наукових досліджень та напрацювання висновків щодо модернізації українського корпоративного законодавства.

Виклад основного матеріалу. У першій половині 2017 року Закон України «Про акціонерні товариства» було доповнено ст. $26^{1}$ «Договір між акціонерами товариства», де, поряд з іншими питаннями здійснення корпоративних прав акціонерами, передбачена відповідальність сторін акціонерного договору. Разом із тим саме поняття цивільно-правової відповідальності є одним із дискусійних у теорії права. Серед великої кількості запропонованих визначень вважаємо виваженою пропозицію про вивчення поняття цивільно-правової відповідальності у його матеріальному та процесуальному значеннях. У матеріальному значенні - це покарання порушника у вигляді покладення додаткового обов'язку чи позбавлення того, що особа має або могла б мати. У процесуальному - це застосовувані юрисдикційними органами примусові заходи до правопорушника, форма реалізації державою своїх функцій владного втручання у процес правового регулювання [2, с. 267-271]. Зважаючи на те, що цивільно-правова відповідальність у матеріальному значенні є приватноправовою категорією, то саме вона і буде розглянута у межах цієї статті, зокрема той її вид, що виникає з акціонерного договору.

Очевидно, що договірна відповідальність виникає з порушення умов договору, яке по суті є їі підставою. Разом із тим у науковій літературі поняття «підстава» й «умова» цивільно-правової відповідальності не завжди розмежовуються, хоча й мають різне правове значення. Так, зазначається, що поняття «підстава» і «умова» відповідальності слід розрізняти, оскільки вони мають різне змістове і юридичне значення. «Підстава» - це те, що породжує якенебудь явище, фундамент, на який останне спирається і який визначає його природу. «Умова» - ті ознаки, які характеризують підставу та без наявності яких явище не може виникнути [3, с. 56]. Таким чином, «підстава» - це юридичний факт, що породжує виникнення певних правовідносин, їх зміну або припинення. У цивілістиці переважає думка, що таким фактом, у зв'язку з яким наступає цивільно-правова відповідальність, $€$ невиконання або неналежне виконання зобов'язань, передбачених договором.

Відповідно до ч. 1, 2 ст. $26^{1}$ Закону України «Про акціонерні товариства» предметом акціонерного договору є реалізація акціонерами прав на акції та/або прав за акціями, передбачених законодавством, статутом та іншими внутрішніми документами товариства. Причому цим договором сторони можуть передбачити як спосіб здійснення вказаних прав, так і обов'язок утримуватися від їх реалізації.

Очевидно, що право на акції може охоплювати як умови їх відчуження (наприклад, продаж третім особам, певним акціонерам, товариству), так й умови та обсяг їх придбання (наприклад, обмеження купівлі цінних паперів більше певного обсягу). У свою чергу договором може передбачатися покладення на його сторони обов'язку погоджувати придбання або відчуження акцій за заздалегідь визначеною ціною та/ або у разі настання визначених у договорі обставин утримуватися від відчуження акцій до настання визначених у договорі обставин, передбачати умови або порядок визначення умов [4, с. 100-104], за яких акціонер-сторона договору вправі або зобов'язана придбати або продати акції товариства тощо.

Питання здійснення прав за акціями або обов'язок утримуватися від їх реалізації здебільшого пов'язані з управлінням товариством. Договір може передбачати обов'язок його сторін голосувати у спосіб, передбачений таким договором, на загальних зборах акціонерів товариства, за винятком випадків, прямо передбачених чинним законодавством, вчиняти або не вчиняти інші дії, пов'язані з управлінням товариством, його припиненням або виділом 3 нього нового товариства тощо. Порушення таких умов договору є підставою виникнення відповідальності для правопорушника. При цьому необхідно зазначити, що відповідальність сторін акціонерного договору може встановлюватися не лише за порушення тих прав (обов'язків), що передбачені договором, а й передбачених чинним законодавством, статутом та іншими внутрішніми документами товариства.

У юридичній літературі часто зазначається, що заходами відповідальності за зобов’язаннями сторін акціонерного договору $є$ стягнення неустойки, відшкодування завданих порушенням договору збитків, виплата компенсації (твердої грошової суми або суми, що підлягає визначенню в порядку, визначеному в акціонерному договорі), інші заходи відповідальності у зв'язку 3 порушенням акціонерного договору [5, с. 97]. Разом із тим вказується, що зазначені заходи цивільної відповідальності є складними у застосуванні до сторін акціонерного договору. Тому на практиці простежуються випадки застосування 
інших форм відповідальності, що притаманні іноземному праву (наприклад, примусовий продаж акцій). Проте як вітчизняна наука, так і практика неоднозначно дають відповідь на питання щодо доцільності надання можливості закріплювати в акціонерному договорі заходів (форм) відповідальності, не передбачених цивільним законодавством i, як наслідок, можливості судового захисту сторін (учасників) у разі невиконання або неналежного виконання учасниками своїх зобов'язань за таким договором [6, с. 61-63].

Якщо цивільно-правова відповідальність розкривається як новий додатковий обов'язок, якого не існувало до правопорушення (Т. С. Абова, А. С. Панова та ін.), то «засобом» відповідальності може розглядатися лише штрафна неустойка. Адже лише вона є обтяженням та слугує покаранням у вигляді покладення на порушника додаткового обов'язку. Як справедливо зазначається у юридичній літературі, «відносинами відповідальності є не всі охоронні правовідносини, змістом яких є нові, обумовлені правопорушенням права та обов'язки сторін, а лише ті з них, де на порушника покладається майнове обтяження» [7, с. 287-299]. Відшкодування (компенсація), яке має відновлюваний характер, по суті, лише повертає сторони у той стан, який існував до правопорушення. У даному випадку завдання шкоди має розглядатися як юридичний факт, що породжує обов'язок відшкодувати (компенсувати) шкоду [8, с. 78-80]. І такий обов'язок є елементом змісту зобов'язання, а не відповідальністю.

Щодо інших заходів, то можна зазначити, що залишається дискусійним питання щодо можливості застосування таких видів відповідальності, як втрата (тимчасове обмеження) права голосу [9, с. 190], а також права на участь у розподілі (одержанні) прибутку в поточному фінансовому періоді. Такі заходи відповідальності натепер не передбачені корпоративним законодавством України, і їх застосування на практиці може призвести до певних труднощів. Наведене грунтується на положеннях ст. 25 Закону України «Про акціонерні товариства», відповідно до якої акціонери-власники простих акцій товариства можуть брати участь у загальних зборах акціонерів із правом голосу з усіх питань його компетенції. Жодних обмежень при цьому вказана норма не містить.

Однак не можна не визнати, що економічне підгрунтя такого заходу відповідальності, як втрата права голосу за порушення положень акціонерного договору, все-таки існує. По-перше, такий підхід формально повністю узгоджується 3 розумінням цивільно-правової відповідальності у матеріальному значенні як покарання у вигляді позбавлення порушника того, що він має або міг би мати. Саме в даному випадку особа позбавляється (обмежується) права голосу. По-друге, така втрата голосу полягає в тому, що якщо акціонерним договором встановлені певні зобов'язання щодо голосування в тій чи іншій ситуації, то у разі порушення таких зобов'язань найбільш ефективним способом попередження подальшого їх порушення в майбутньому є позбавлення права голосу акціонера, який їх порушив, оскільки у разі встановлення цього заходу відповідальності він фактично не зможе повторно порушити це зобов'язання. У такій ситуації позбавлення права голосу може попередити і майбутні порушення виконання зобов'язань щодо голосування, хоча й без відшкодування збитків, заподіяних порушенням, завданих у минулому. Відшкодувати ці збитки було б можливо за допомогою того, що частина або весь прибуток товариства, який відповідно до наявних акцій у особи, яка порушила зобов'язання, могла би бути перерозподілена на покриття збитків [5, с. 104]. Однак при цьому має йтися виключно про тимчасове, а не постійне позбавлення права голосу або позбавлення права голосу з питань, які стали підставою порушення акціонерного договору.

Слід зазначити, що в окремих країнах успішно використовується визнання недійсним рішення загальних зборів акціонерів як захід відповідальності за невиконання або неналежне виконання зобов'язань, що $€$ похідними з акціонерного договору. Наприклад, у Німеччині встановлено, що рішення загальних зборів акціонерів може бути оскаржене у разі порушення положень акціонерного договору, але лише якщо сторонами такого договору є всі акціонери відповідного акціонерного товариства. При цьому, як справедливо зазначає X. Ода, визнання недійсним рішення загальних зборів у такій ситуації, по суті, не суперечить договірній природі акціонерного договору, тому що домовленості з голосування, укладені між усіма акціонерами, можуть призвести до таких же наслідків, що й акти корпоративного права в тому ступені, у якому учасники однаковою мірою пов'язані зобов'язаннями за домовленістю [10, с. 155].

Дослідники акціонерних договорів також зазначають, що у разі невиконання чи неналежного виконання однією чи декількома його сторонами покладених на них договірних зобов'язань, як-от голосування невідповідним чином на загальних зборах корпорації, порушення встановленого договором 
порядку відчуження корпоративних прав тощо, решта сторін можуть відмовитись від нього у якості заходу оперативного впливу на порушників [11, с. 188]. I з такою думкою можна погодитися, адже, відповідно до ст. 611 ЦК України у разі порушення зобов'язань можуть настати для порушника такі правові наслідки, як: припинення зобов'язання внаслідок односторонньої відмови від зобов'язання, якщо це встановлено договором або законом; зміна умов зобов'язання; розірвання договору. Разом із тим розірвання акціонерного договору як вид відповідальності за його ж невиконання чи неналежне виконання виглядає доволі сумнівно. Адже учасник і так не бажає виконувати його умови. Тому, на думку М. В. Трубіної, у разі порушення зобов'язань, передбачених акціонерним договором, доцільно було б, щоб сторона, що вчинила порушення, була присуджена до виконання зобов'язання в натурі. Однак і при цьому не слід переоцінювати значення такого способу захисту прав акціонерів. Наприклад, у разі, коли сторона порушуе зобов’язання про здійснення права голосу способом, який передбачений в укладеному нею договорі, вимога про присудження до виконання обов'язку в натурі буде ефективною лише тоді, коли вона заявлена вчасно, по суті, до прийняття загальними зборами акціонерів відповідного рішення. 3 практичної точки зору, присудження до реального виконання зобов'язань у випадку, якщо предметом акціонерного договору є зобов'язання 3 порядку голосування, буде малоефективним способом захисту інтересів сторін акціонерних договорів [12, с. 165-166, 168].

\section{Висновки}

Таким чином, цивільно-правова відповідальність сторін акціонерного договору - це покарання порушника у вигляді покладення на нього додаткового обов'язку чи позбавлення того, що він уже має або міг би мати. Підставами такої відповідальності можуть бути: порушення умов договору, порушення прав та обов'язків, передбачених чинним законодавством, статутом чи іншими внутрішніми документами товариства.

Зроблені висновки свідчать про необхідність проведення більш глибоких наукових досліджень цивільно-правової відповідальності сторін акціонерного договору, підстав та умов її виникнення, підстави звільнення тощо.

\section{Список використаних джерел:}

1. Корпоративне право Польщі та України : монографія / Васильєва В. А., Герберт Анджей, Ковалишин О. Р. та ін. ; за ред. проф. В. А. Васильєвої. Івано-Франківськ, 2016. 377 с.

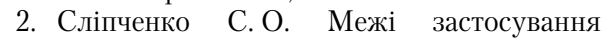
поняття «цивільно-правова відповідальність». Модернізація иивільно-правової відповідальності. Матвєєвські иивілістичні читання : матеріали міжнар. наук.-практ. конф. (м. Київ, 18 жовт. 2019 р.). / Р. А. Майданик, В. В. Цюра та ін.; відп. ред. Р. А. Майданик. Київ, 2019. С. 267-271.

3. Смирнов В. Т., Собчак А. А. Общее учение о деликтных обязательствах в советском гражданском праве : учебное пособие. Ленинград : ЛГУ, 1983. $152 \mathrm{c}$.

4. Слипченко А. С. Отчуждение и переход объектов гражданского оборота в Украине: соотношение понятий. LEGEA I VIA A. № 10/2 (322). 2018. C. $100-104$.

5. Иноземцев М. И. Ответственность сторон за нарушение акционерного соглашения по праву России и зарубежных государств : дис. ... канд. юрид. наук: 12.00.03. Москва, 2017. 185 с.

6. Жорнокуй Ю. М. Особливості відповідальності сторін за акціонерним договором: зобов'язальна чи корпоративна природа. Модернізачія иивільно-правової відповідальності. Матвєєвські иивілістичні читання : матеріали міжнар. наук.-практ. конф. (м. Київ, 18 жовт. 2019 р.). / Р. А. Майданик, В. В. Цюра та ін.; відп. ред. Р. А. Майданик. Київ, 2019. С. 61-63.

7. Карнаух Б. Сутність і явище цивільно-правової відповідальності. Вісник академії правових наук України. 2012. № 2. С. 287-299.

8. Сліпченко С. О. Щодо цивільно-правової відповідальності. Шості юридичні диспути з актуальних проблем приватного права, присвячені пам'яті Є. В. Васьковского (до 150-річчя від дня його народження) : матеріали Міжнар. наук.практ. конф. (Одеса, 22 травня 2015 р.) / відповід. ред. І. С. Канзафарова. Одеса: Астропринт, 2015. С. $78-80$.

9. Жорнокуй В. Г. Здійснення права участі в управлінні господарським товариством. Право $i$ безпека. 2014. № 4. С. 187-192.

10. Ода Х. Акционерные соглашения: осторожный шаг вперед. Вестник гражданского права. 2010. № 1. C. 132-161.

11. Сигидин М. М. Корпоративний договір : дис. ... канд. юрид. наук: 12.00.03. Івано-Франківськ, 2016. 188 с.

12. Трубина М. В. Гражданско-правовое регулирование акционерных соглашений в России и странах континентальной Европы : дис. ... канд. юрид. наук : 12.00.03. Москва, 2015. 194 с. 
The author of the article studies the problems of civil liability of the parties to a shareholders' agreement. Based on the division of this concept into its substantive and procedural meaning, the author considers that civil liability of the parties to such an agreement in the substantive sense is the punishment of the offender by imposing on him an additional obligation or depriving him of everything he already has or could have. The author has substantiated that the violation of an agreement's conditions is the basis for liability for the offender. Herewith, it has been noted that the liability of the parties to a shareholders' agreement may be established not only for the violation of those rights (obligations) stipulated by the agreement, but also provided by the current legislation, the charter and other internal documents of the company.

One of the key issues discussed in the article is the ability to apply such type of liability as the loss of a voting right to any issue by a party of a shareholders' agreement that may be considered at the general meeting. It is argued that this approach is fully consistent with the understanding of civil liability as punishment in the form of depriving the offender of what he or she has or might have. In this case, the person is deprived (restricted) of voting rights. Moreover, if a shareholders' agreement establishes certain voting obligations in a particular situation, then in case of the violation of such obligations, the most effective way of preventing their further violations is deprivation of such a shareholder of the voting right. The author of the article believes that deprivation of the right to vote can also prevent future violations of voting obligations, though without compensation for damages caused by violations committed in the past. To compensate those losses would be possible by the fact that part or all of the profits of the company, which, according to the shares available to the entity that violated the obligations, could be redistributed to cover the losses.

The indicated testifies to the need for deeper scientific studies of civil liability of the participants of shareholders agreement, the grounds and conditions of its occurrence, grounds for dismissal, etc.

Key words: contract, civil liability, shareholder, shareholders' agreement, liability measures, compensation. 